\title{
Plants as a realized niche for Listeria monocytogenes
}

\author{
Hoai-Nam Truong ${ }^{1}$, Dominique Garmyn ${ }^{2}$, Laurent Gal ${ }^{3}$, Carine Fournier ${ }^{3}$, Yann Sevellec ${ }^{4}$, \\ Sylvain Jeandroz ${ }^{3}$, and Pascal Piveteau ${ }^{1}$ \\ ${ }^{1}$ INRAE \\ ${ }^{2}$ Burgundy Franche-Comté University \\ ${ }^{3}$ AgroSup Dijon \\ ${ }^{4}$ Paris-Est University
}

November 27, 2021

\begin{abstract}
Listeria monocytogenes is a human pathogen. It is the causative agent of listeriosis, the leading cause of bacterial-linked foodborne mortality in Europe and elsewhere. Outbreaks of listeriosis have been associated with the consumption of fresh produce including vegetables and fruits. In this review we summarize current data providing direct or indirect evidence that plants can serve as habitat for L. monocytogenes, enabling this human pathogen to survive and grow. The current knowledge of the mechanisms involved in the interaction of this bacterium with plants is addressed, and whether this foodborne pathogen elicits an immune response in plants is discussed.
\end{abstract}

\section{Hosted file}

MB032021080414.pdf available at https://authorea.com/users/448304/articles/547110-plants-asa-realized-niche-for-listeria-monocytogenes 